\title{
Quantification of Galantamine in Sternbergia Species by High Performance Liquid Chromatography
}

\section{Sternbergia Türlerinde Yüksek Performanslı Sıvı Kromatografisi ile Galantamin Miktar Tayini}

\author{
(D) Özlem Bahadır ACIKARA, (D) Betül Sever YILMAZ*, (D) Dilhun YAZGAN, (D) Gülçin Saltan ișCAN \\ Ankara University, Faculty of Pharmacy, Department of Pharmacognosy, Ankara, Turkey
}

\begin{abstract}
Objectives: This study describes the qualitative and quantitative analysis of galantamine in Sternbergia species growing in Turkey.

Materials and Methods: Galantamine was isolated from Sternbergia fischeriana bulbs and the structure of the compound elucidated by spectroscopic methods. The qualitative and quantitative analysis of galantamine was investigated in Sternbergia lutea subsp. lutea, S. lutea subsp. sicula, Sternbergia candida, S. fischeriana, and Sternbergia clusiana using a specially developed and validated high performance liquid chromatography (HPLC) method. Results: S. lutea subsp. sicula had the highest content of galantamine, i.e., $0.0165 \pm 0.0002 \mathrm{~g} / 100 \mathrm{~g}$. The limits of detection and quantification were $7.5 \mu \mathrm{g}$ and $25 \mu \mathrm{g}$, respectively.

Conclusion: Isolation of galantamine from S. fischeriana growing in Turkey is reported for the first time. An HPLC method was developed for identification and quantification of galantamine in Sternbergia species.
\end{abstract}

Key words: Galantamine, HPLC, Sternbergia spp.

öz

Amaç: Bu çalışmada Türkiye'de yetişen Sternbergia türlerinin galantamin içeriklerinin kalitatif ve kantitatif analizi amaçlanmıştır.

Gereç ve Yöntemler: Galantamin Sternbergia fischeriana yumrularından izole edilmiş ve yapısı spektroskopik yöntemler kullanılarak aydınlatılmıştır. Sternbergia lutea subsp. lutea, S. lutea subsp. sicula, Sternbergia candida, S. fischeriana ve Sternbergia clusiana türlerinin galantamin içeriği kalitatif ve kantitatif olarak yeni geliştirilen ve valide edilmiş bir yüksek performanslı sıvı kromatografisi (HPLC) yöntemi kullanılarak yapılmıștır.

Bulgular: S. lutea subsp. sicula türünün $0.0165 \pm 0.0002 \mathrm{~g} / 100 \mathrm{~g}$ olarak en yüksek galantamin içeriğine sahip olduğu belirlenmiştir. Galantamin için saptama ve kantifikasyon sınırı değerleri sırasıyla $7.5 \mu \mathrm{g}$ ve $25 \mu \mathrm{g}$ olarak belirlenmiștir.

Sonuç: Türkiye'de yetișen S. fischeriana türünden galantamin izolasyonu ilk kez bu çalışma ile rapor edilmiştir. Ayrıca bu çalışma ile Sternbergia türlerinin galantamin içeriğinin tespit edilmesi ve miktar tayini için yeni bir HPLC metodu geliştirilmiştir.

Anahtar kelimeler: Galantamin, HPLC, Sternbergia spp.

*Correspondence: E-mail: sever@pharmacy.ankara.edu.tr, Phone: +90 5323006994 ORCID-ID: orcid.org/0000-0003-2084-9514

Received: 22.09.2017, Accepted: 28.12.2017

๑Turk J Pharm Sci, Published by Galenos Publishing House. 


\section{INTRODUCTION}

Galantamine is approved by the Food and Drug Administration for the treatment of mild to moderate Alzheimer's disease.' Razadyne ${ }^{\circledR}$ (formerly Reminy ${ }^{\circledR}$ ) and Nivalin ${ }^{\circledast}$ are licensed drugs of galantamine, currently available on the market. ${ }^{2}$ This drug inhibits acetylcholinesterase enzyme reversibly and acts as an allosteric modulator of the nicotinic cholinergic receptor. Interaction potentiates cholinergic nicotinic neurotransmission by modulating ion channel activity in the presence of acetylcholine. ${ }^{1-4}$ This drug provides the requisite cholinergic stimulation without producing desensitization. Furthermore, galantamine appears to be a more powerful elevator of frontal cortical dopamine levels compared to other cholinesterase inhibitors such as donepezil.' Galantamine exerts neuroprotection on neuronal cell cultures subjected to oxidative stress or amyloid beta stress. Neuroprotection in rat hippocampal slices subjected to oxygen and glucose deprivation followed by a reoxygenation period was also demonstrated by galantamine. Galantamine also acts as a neuroprotective agent in an in vivo model of global cerebral ischemia, even when given after the ischemic insult. 5.6

Galantamine was firstly isolated from the snowdrop, Galanthus woronowii. Generally Amaryllidaceae plants including Narcissus, Galanthus, Lycoris, and Leucojum species are used for extraction of galantamine. Leucojum aestivum is known as the main source of this compound. Narcissus species also contain galantamine in varying amounts from trace amounts to as much as $2.5 \%$ of dry weight. Synthetic methods for production of galantamine have been developed; however due to their high cost, plants are still the main sources for galantamine production.?

The galantamine content of Amaryllidaceae plants was investigated using different high performance liquid chromatography (HPLC) methods. ${ }^{7}$ An isocratic solvent system consisting of an acetonitrile:methanol:water (containing 7.5 $\mathrm{mM}$ triethanolamine, $\mathrm{pH}$ 6.9) mixture as mobile phase was used for detecting galantamine on an RP-C8 column in $L$. aestivum. ${ }^{8}$ In another study conducted on L. aestivum, an acetonitrile:methanol:buffer pH 4.5 (10:10:80) mixture was used for elution on an RP-C18 column to determine galantamine amount. ${ }^{2}$ Lubbe et al. ${ }^{10}$ also reported HPLC analysis of galantamine in Narcissus pseudonarcissus on a $\mathrm{C} 18$ column using $10 \%(\mathrm{v} / \mathrm{v})$ acetonitrile in water containing $0.1 \%$ trifluoroacetic acid (TFA) as mobile phase. Galanthus elwesii was also analyzed for its galantamine content by using a mobile phase comprising a TFA:water:ACN (0.01:90:10) mixture on an RP-
C18 column.1" Petruczynik et al. ${ }^{12}$ analyzed galantamine on an RP-C18 column with a mobile phase containing $5 \%$ MeCN, $20 \%$ acetate buffer at $\mathrm{pH} 3.5$, and $0.025 \mathrm{~mL}^{-1}$ diethylamine as well as on an SCX column using an $8 \% \mathrm{MeCN}$ and phosphate buffer at $\mathrm{pH} 2.5$ mixture as mobile phase in L. aestivum, Leucojum vernum var. carpaticum, Galanthus nivalis, Zepyranthes rosea, and Clivia minata.The genus Sternbergia Waldst. and Kit. (Amaryllidaceae) is represented by eight species and they are widely distributed from the East Mediterranean to Caucasia. In Turkey six taxa of this genus grow naturally. ${ }^{13}$ Sternbergia species are well known due to their alkaloid contents, i.e., lycorine and galantamine, with interesting pharmacological properties. ${ }^{14,15}$ Alkaloids including lycorine, homolycorine, haemanthidine, haemanthamine, $6 \alpha-$ and $6 \beta$-hydroxy-haemanthamine, and tazettine have been isolated from Sternbergia species. ${ }^{14-18}$ It has been reported that Sternbergia species contain especially crinine-type and lycorine-type Amaryllidaceae alkaloids. ${ }^{13}$

In order to investigate new sources for galantamine, Sternbergia species were investigated using HPLC in the current study. Sternbergia lutea, Sternbergia sicula, Sternbergia fischeriana, Sternbergia clusiana, and Sternbergia colchiciflora, which were collected from different locations of Anatolia, were analyzed using HPLC. An isocratic system was developed and used for HPLC analysis. Galantamine, which was isolated from $S$. fischeriana bulbs previously, was used for quantification of the galantamine contents of S. lutea, S. sicula, S. fischeriana, S. clusiana, and S. colchiciflora.

\section{EXPERIMENTAL}

\section{Plant materials}

Sternbergia species were collected from different parts of Anatolia as shown in Table 1. Voucher specimens are kept at the Herbarium of Ankara University, Faculty of Pharmacy with their herbarium numbers (Table 1).

\section{Isolation of galantamine}

Galantamine was isolated from S. fischeriana bulbs. The dried bulbs $(500 \mathrm{~g})$ were extracted with ethanol $(5 \mathrm{~L})$ by percolation. Ethanolic extract was filtered and concentrated under vacuum at $50^{\circ} \mathrm{C}$ by evaporation. The $\mathrm{pH}$ of the extract was adjusted to 3 by addition of $5 \% \mathrm{HCl}$. After filtration $\mathrm{CHCl}_{3}$ was used for liquidliquid extraction. The chloroform part was concentrated under vacuum by evaporation to obtain extract A (13.7538 g), which contained lycorine and tazettine. The remaining acidic-water part was extracted with $\mathrm{CHCl}_{3}$ after addition of alkali solution

Table 1. Plant materials, collected places, and herbarium numbers

\begin{tabular}{lll} 
Species & Herbarium numbers & Collection sites \\
\hline Sternbergia candida Mathew \& T.Baytop & AEF 23794 & Muğla-Fethiye \\
\hline Sternbergia clusiana (Ker Gawl.) Ker Gawl. ex Sprengel & AEF 23697 & Kahramanmaraş-Göksun \\
\hline Sternbergia fischeriana (Herbert) Rupr. & AEF 23793 & Antakya-Yayladağ \\
\hline Sternbergia lutea subsp. lutea Waldst. \& Kit. & AEF 23694 & İzmir-Torbalı \\
\hline Sternbergia lutea subsp. sicula Tineo ex Guss. & AEF 23695 & Muğla-Marmaris \\
\hline
\end{tabular}


$\left(\mathrm{NH}_{4} \mathrm{OH} 25 \%\right.$ to obtain $\mathrm{pH}$ 8). The concentrated chloroform part gave extract B (1.9712 g). Extract B was separated by Chromatotron on aluminum oxide GF Gypsum (Merck 1092) plates. Elution was performed with a $\mathrm{CHCl}_{3}: \mathrm{MeOH}$ (9:1) mixture. Fractions 1-4 were subjected to further separation by preparative TLC on precoated TLC sheets (Merck 5744) eluting with $\mathrm{CHCl}_{3}: \mathrm{MeOH}(85: 15)$ to obtain galantamine $(5.04 \mathrm{mg}) .{ }^{19}$ The structure of the isolated compound was elucidated by ${ }^{1} \mathrm{H}-\mathrm{NMR}$ and comparison of these data with the literature.19-23

Galantamine: ${ }^{1} \mathrm{H}-\mathrm{NMR}\left(\mathrm{CDCl}_{3}, 400 \mathrm{MHz}, \delta, \mathrm{ppm}, \mathrm{J} / \mathrm{Hz}\right): 6.63(1 \mathrm{H}$, d, J=8 Hz, H-12); 6.53 (1H, d, J=8 Hz, H-11); 6.02 (1H, d, J=10.3 $\mathrm{Hz}, \mathrm{H}-4) ; 6.00$ (1H, d, J=10.3 Hz, H-3); 4.47 (1H, brs, H-16); 4.10

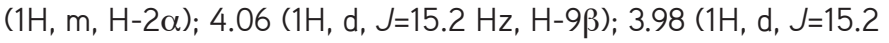
$\mathrm{Hz}, \mathrm{H}-9 \alpha) ; 3.05(1 \mathrm{H}, \mathrm{m}, \mathrm{H}-7 \alpha) ; 2.95(1 \mathrm{H}, \mathrm{m}, \mathrm{H}-7 \beta) ; 2.56(1 \mathrm{H}, \mathrm{m}$, $H-1 \alpha), 2.45(1 H, m, H-1 \beta) ; 1.50(1 H, m, H-6 \alpha) ; 1.47(1 H, m, H-\beta)$, $3.72\left(\mathrm{~s}, \mathrm{O}-\mathrm{CH}_{3}\right), 2.51\left(\mathrm{~s}, \mathrm{~N}-\mathrm{CH}_{3}\right)$.

\section{HPLC analysis}

HPLC analyses were carried out using an Agilent LC 1100 model chromatograph (Agilent Technologies, Inc., Santa Clara, CA, USA). The diode-array detector was set at wavelength 292 $\mathrm{nm}$ and peak areas were integrated automatically by computer using Agilent software. The chromatograms were plotted and processed using the above-mentioned software. Separation was carried out using a SUPELCOSIL LC-18 column $(250 \times 4.6 \mathrm{~mm}$ i.d.; $5 \mu \mathrm{m}$; Supelco, Bellefonte, PA, USA). The mobile phase was made up of ammonium carbonate (Laboratory BDH Reagent, Poole, UK) water solution (purified water was obtained by using Milli-Q Plus System (Millipore Corp., Molsheim, France) and acetonitrile (HPLC grade $99.93 \%$ purity, Sigma-Aldrich $270717)(85: 15 \mathrm{v} / \mathrm{v})$ applied at a flow rate of $1 \mathrm{~mL} / \mathrm{min}$, column temperature $24^{\circ} \mathrm{C}$, and $20 \mu \mathrm{L}$ portions were injected into the liquid chromatography system.

\section{Preparation of standard and sample solutions}

Standard stock solution was prepared in $1 \mathrm{mg} / \mathrm{mL}$ concentration. First $10 \mathrm{mg}$ of galantamine was weighed in a $10 \mathrm{~mL}$ volumetric flask and then it was dissolved in $10 \mathrm{~mL}$ of $1 \% \mathrm{H}_{2} \mathrm{SO}_{4}$. Different concentration levels $(0.025 \mathrm{mg} / \mathrm{mL}, 0.05 \mathrm{mg} / \mathrm{mL}, 0.075 \mathrm{mg} /$ $\mathrm{mL}, 0.1 \mathrm{mg} / \mathrm{mL}, 0.2 \mathrm{mg} / \mathrm{mL}, 0.3 \mathrm{mg} / \mathrm{mL}$, and $0.4 \mathrm{mg} / \mathrm{mL}$ ) were prepared by diluting the stock solution.

Sample solutions were prepared by extraction of dried and powdered bulbs $\left(10 \mathrm{~g}\right.$ ) of each plant with $1 \% \mathrm{H}_{2} \mathrm{SO}_{4}$ by rinsing at room temperature for 7 days. The extraction procedure was tested with Mayer's reagent to be sure all alkaloids were extracted. Each extract was filtered through a $0.45-\mathrm{mm}$ membrane filter and adjusted to a final volume of $500 \mathrm{~mL}$ with acidic solution.

\section{Limits of detection and quantification}

The limit of detection (LOD) and limit of quantification (LOQ) were established at a signal to noise ratio $(\mathrm{S} / \mathrm{N})$ of 3 and 10 , respectively. $L O D$ and $L O Q$ concentrations were experimentally verified by six injections of galantamine. The precision of the method (intra-day variations of replicate determinations) was checked by injecting galantamine nine times at the LOQ level.

\section{RESULTS AND DISCUSSION}

To date, any Sternbergia species growing in Turkey has been reported that does not contain galantamine. In addition, galantamine has not been determined in any Sternbergia species growing in Turkey. However in the present study galantamin was detected and quantified in Sternbergia species. ${ }^{13,24}$ This study led to the isolation of this compound from the bulbs of S. fischeriana collected from Yayladağ in Antakya Province. Additionally, the current study describes the development of a method for identifying and quantifying galantamine in Sternbergia species. Good separation and determination of this compound were achieved using a mobile phase consisting of ammonium carbonate and acetonitrile $(85: 15 \mathrm{v} / \mathrm{v})$ on a SUPELCOSIL LC-18 column $(250 \times 4.6 \mathrm{~mm} \times 5 \mu \mathrm{m})$ at wavelength $292 \mathrm{~nm}$ as shown in Figures 1 and 2.

$\mathrm{LOD}$ and $\mathrm{LOQ}$ values were $7.5 \mu \mathrm{g}$ and $25 \mu \mathrm{g}$, respectively. Table 2 shows the wavelength measured, the calculated calibration curve, and the LOD and $L O Q$ results for this compound. The precision of the method is expressed as the relative standard

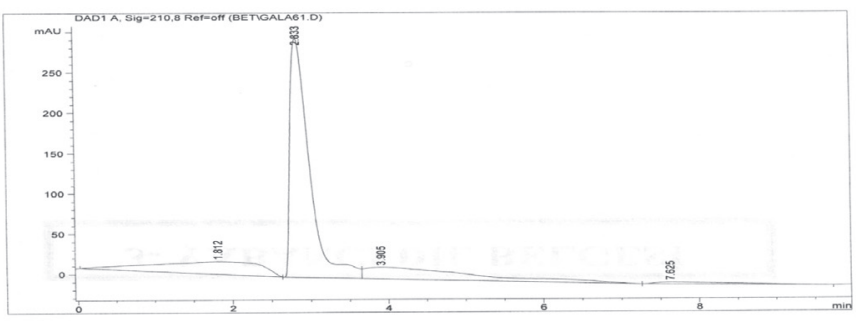

Figure 1. HPLC chromatogram of galantamine

HPLC: High performance liquid chromatography, DAD: Diod-array detector

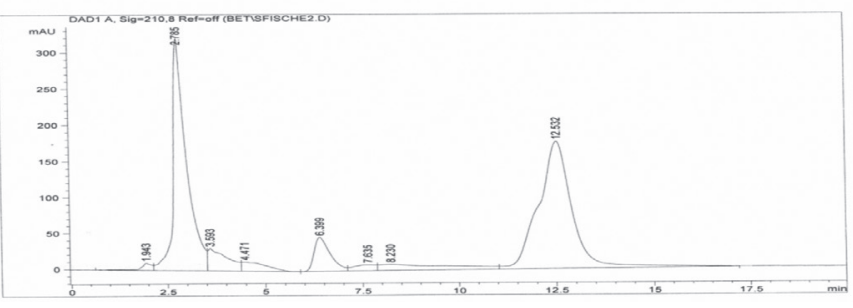

Figure 2. HPLC chromatogram of Sternbergia fischeriana

HPLC: High performance liquid chromatography, DAD: Diod-array detector
Table 2. Linearity results, LOQ, and LOD

\begin{tabular}{lllccccc} 
Compound & $\lambda$ & Equation & $r^{2}$ & Slope RSD \% & $\begin{array}{c}\text { Intercept RSD \% } \\
(\mu \mathrm{Lg})\end{array}$ & $\begin{array}{l}\text { LOD } \\
(\mu \mathrm{g})\end{array}$ \\
\hline Galantamine & 292 & $\mathrm{Y}=118484.33 \mathrm{X}+448.2$ & 0.995 & 2.0594 & 4.4493 & 25 \\
\hline
\end{tabular}

LOQ: Limit of quantification, LOD: Limit of detection, RSD: Relative standard deviation 
Table 3. Galantamine contents of Sternbergia species

\begin{tabular}{ll} 
Species & $\begin{array}{l}\text { Galantamine } \%(n=3, \text { mean } \pm \\
\text { standard deviation) }\end{array}$ \\
\hline Sternbergia candida & $0.0092 \pm 0.0005$ \\
\hline Sternbergia clusiana & $0.0077 \pm 0.0001$ \\
\hline Sternbergia fischeriana & $0.0069 \pm 0.0006$ \\
\hline Sternbergia lutea subsp. lutea & $0.0100 \pm 0.0005$ \\
\hline Sternbergia lutea subsp. sicula & $0.0165 \pm 0.0002$ \\
\hline
\end{tabular}

deviation at the LOQ level.

The presence of galantamine (Figure 3) in S. lutea subsp. lutea, S. lutea subsp. sicula, S. candida, S. fischeriana, and S. clusiana was analyzed quantitatively and qualitatively by HPLC. The current study results, as shown in Table 3, revealed that all plant samples contain galantamine and the highest content was determined in S. lutea subsp. sicula $(0.0165 \pm 0.0002 \% \mathrm{dw})$ followed by $S$. lutea subsp. lutea $(0.0100 \pm 0.0005 \% \mathrm{dw})$. According to previous studies, G. woronowii and L. aestivum contain 0.003-0.506\% and $0.0028-0.2104 \%$ galantamine, respectively. ${ }^{25.26}$ The galantamine content ranged from 0.05 to $0.36 \mathrm{mg} / \mathrm{g} \mathrm{dw}$ in the bulbs of $\mathrm{G}$. nivalis and from 0.3 to $0.033 \mathrm{mg} / \mathrm{g} \mathrm{dw}$ in the bulbs of Narcissus tazetta samples collected from different locations in Iran. According to the results, geographical regions and cultural practices affected the chemical composition of the plants. The chemical variations can be attributed to environmental factors. ${ }^{7}$ L. aestivum plants collected during different periods of vegetation were analyzed for their galantamine contents and the amounts were determined as $0.13 \%$ and $0.14 \%$, respectively, for the plant in bloom and fructification, respectively. ${ }^{9}$ According to Petruczynik et al. ${ }^{12}$, different extraction procedures such as maceration, extraction in an ultrasonic bath, and extraction in an ultrasonic bath following maceration yielded different amounts of galantamine. Galantamine content in L. aestivum was determined as $0.0196 \mathrm{mg} / \mathrm{mL}, 0.0273 \mathrm{mg} / \mathrm{mL}$, and 0.0949 $\mathrm{mg} / \mathrm{mL}$, respectively, by the mentioned extraction procedures. Ultrasonic bath extraction following maceration induced a relatively high amount of galantamine extraction. In the same study the highest amount of galantamine was determined in $L$. aestivum roots with $2.3524 \mathrm{mg} / \mathrm{g} \mathrm{dw}$, followed by leaves with

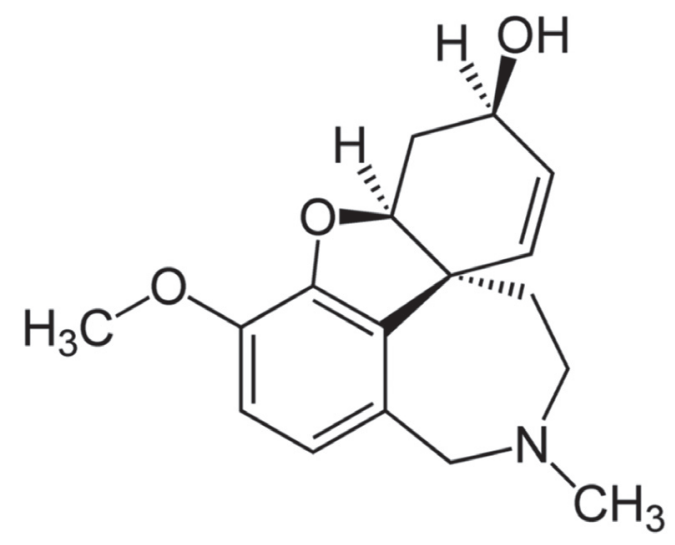

Figure 3. Structure of galantamine
$1.6611 \mathrm{mg} / \mathrm{g} \mathrm{dw}$. Z. rosea bulbs and C. minata leaves as well as roots were found to contain $0.8384 \mathrm{mg} / \mathrm{g} \mathrm{dw}$ and $0.1489 \mathrm{mg} / \mathrm{g}$ $\mathrm{dw}$, and $0.0284 \mathrm{mg} / \mathrm{g} \mathrm{dw}$ galantamine, respectively. In all parts of $G$. nivalis galantamine content varied from $0.0003 \mathrm{mg} / \mathrm{g}$ $\mathrm{dw}$ to $0.0178 \mathrm{mg} / \mathrm{g} \mathrm{dw}$. G. elwesii samples collected from two different locations in Turkey, İzmir and Karaburun, contained $0.026 \%$ and $0.007 \%$ galantamine, respectively. ${ }^{11}$ The amount of galantamine also varied from $2.36 \mathrm{mg} / \mathrm{g} \mathrm{dw}$ to $3.32 \mathrm{mg} / \mathrm{g} \mathrm{dw}$ in $N$. pseudonarcissus bulbs collected from the Netherlands. ${ }^{10}$ According to our results, galantamine content of the Sternbergia species was lower than that of $L$. aestivum when they were compared. The current study's results revealed that Sternbergia species are not valuable sources for galantamine extraction. Differences in galantamine content among all the investigated species could be explained by the existence of chemotype. Furthermore, a number of factors such as temperature, season, stages of maturity, geographical origin, climatic conditions, and soil can affect the phytochemical content of plants. ${ }^{27,28}$ Plants cultivated under different conditions exhibit an alteration in the quantity of phytochemicals and therefore display varied therapeutic effects. ${ }^{29,30}$

\section{CONCLUSIONS}

The present study is the first report of galantamine isolation from Sternbergia species growing in Turkey. An HPLC method was developed for identification and quantification of galantamine in the genus Sternbergia. The presence of galantamine could be related to growing conditions such as temperature, season, climatic conditions, soil, or stages of maturity as well as geographical origin. Chemotype of the mentioned species could be also the reason for the presence of galantamine in Sternbergia species. Therefore, further studies will be planned to investigate Sternbergia species collected from different locations in Turkey for their galantamine contents.

Conflict of Interest: No conflict of interest was declared by the authors.

\section{REFERENCES}

1. Lindenmayer JP, Khan A. Galantamine augmentation of longacting injectable risperidone for cognitive impairments in chronic schizophrenia. Schizophr Res. 2011;125:267-277.

2. Berkov S, Codina C, Bastida J. A Global Perspective of Their Role in Nutrition and Health. In Tech, Rijeka-Crotia 2012:235-254.

3. Heinrich M, Lee Teoh $\mathrm{H}$. Galantamine from snowdrop-The development of a modern drug against Alzheimer's disease from local caucasian knowledge. J Ethnopharmacol. 2004;92:147-162.

4. Wattmo C, Wallin AK, Minthon L. Progression of mild Alzheimer's disease: knowledge and prediction models required for future treatment strategies. Alzheimer Res Ther. 2013;5:44.

5. Madrigal JL, Garcia-Bueno B, Caso JR, Perez-Nievas BG, Leza JC. Stress-induced oxidative changes in brain. CNS Neurol Disord Drug Targets. 2006;5:561-568.

6. Sethi G, Sung B, Aggarwal BB. Nuclear factor-kappaB activation: from bench to bedside. Exp Biol Med (Maywood). 2008;233:21-31. 
7. Khonakdari MR, Mirjalili MH, Gholipour A, Rezadoost H, Farimani MM. Quantification of galantamine in Narcissus tazetta and Galanthus nivalis (Amaryllidaceae) populations growing wild in Iran. Plant Genet Resour. 2018;16:188-192.

8. Pavlov A, Berkov S, Courot E, Gocheva T, Tuneva D, Pandova B, Georgiev M, Georgiev V, Yanev S, Burrus M, Ilieva M. Galanthamine production by Leucojum aestivum in vitro systems. Process Biochem. 2007;42:734-739.

9. Klosi R, Mersinllari M, Gavani E. Galantamine content in Leucojum aestivum populations grown in northwest Albania. AJPhSci. 2016;3:1-3.

10. Lubbe A, Pomahacova B, Choi YH, Verpoorte R. Analysis of Metabolic Variation and Galanthamine Content in Narcissus Bulbs by $1 \mathrm{H}$ NMR. Phytochem Anal. 2010;21:66-72.

11. Kaya Gl, Çiçek Polat D, Emir A, Bozkurt Sarıkaya B, Onur MA, Ünver Somer N. Quantitative Determination of Galantamine and Lycorine in Galanthus elwesii by HPLC-DAD. Turk J Pharm Sci. 2014;11:107-112.

12. Petruczynik A, Misiurek J, Tuzimski T, Uszynski R, Szymczak G, Chernetskyy M, Waksmundzka-Hajnos M. Comparison of different HPLC systems for analysis of galnatamine and lycorine in various species of Amaryllidaceae family. J Liq Chromatogr Relat Technol. 2016;39:574579.

13. Saltan Çitoğlu G, Sever Yılmaz B, Bahadır Ö. Quantitative analysis of lycorine in Sternbergia species growing in Turkey. Chem Nat Comp. 2008;44:826-828.

14. Çitoğlu GS, Acıkara OB, Yılmaz BS, Ozbek H. Evaluation of analgesic, anti-inflammatory and hepatoprotective effects of lycorine from Sternbergia fisheriana (Herbert) Rupr. Fitoterapia. 2012;83:81-87.

15. Tanker M, Çitoğlu GS, Gümüșel B, Şener B. Alkaloids of Sternbergia clusiana and their analgesic effects. Int J Pharmacog. 1996;34:194-197.

16. Çitoğlu GS. Alkaloids of Sternbergia candida Mathew \& T. Baytop. J Fac Phar Gazi. 1998:15:93.

17. Çitoğlu GS, Tanker M, Gümüşel B. Antiinflammatory effects of lycorine and haemanthidine. Phytother Res. 1996;12:205.

18. Yurdaışık D. Pharmacognostical Researches on the Alkaloids of Sternbergia fischeriana. Ankara. Master Thesis, Ankara University; 2005.

19. Bastida J, Viladomat F, Llabrés JM, Codina C, Feliz M, Rubiralta M. Alkaloids from Narcissus confuses. Phytochemistry. 1987;26:1519-1524.
20. Harlem D, Martin MT, Thal C, Guillou C. Synthesis and structure activity relationships of open d-ring galanthamine analogues. Bioorg Med Chem Lett. 2003;13:2389-2391.

21. Liang PH, Liu JP, Hsin LW, Cheng CY. Intramolecular Heck Cyclization to the Galanthamine-type Alkaloids: Total Synthesis of $( \pm)$-Lycoramine. Tetrahedron. 2004;61:11655-11660.

22. Berkov S, Sidjimova B, Eustatieva L, Popov S. Intraspecific variability in the alkaloid metabolism of Galanthus elwesii. Phytochemistry. 2004:65:579-586.

23. Kaya Gi. Sternbergia Waldst. \& Kit. türlerinin kimyasal bileşikleri ve biyolojik aktiviteleri. Marmara Pharm. 2001;15:52-57.

24. Çiçek D, Ünver Somer N, Kaya Gi. Quality control and anticholinesterase activity determinations on Sternbergia sicula. Marmara Pharm. 2010;14:121-124.

25. Emir A, Çiçek Polat D, Kaya Gl, Sarıkaya B, Onur MA, Ünver Somer N. Simultaneous determination of lycorine and galanthamine in Galanthus woronowii by HPLC-DAD. Acta Chromatogr. 2013;25:755-764.

26. Georgieva L, Berkov S, Kondakova V, Bastida J, Viladomat F, Atanassov A, Codina C. Alkaloid variability in Leucojum aestivum from wild populations. Z Naturforsch C. 2007;62:627-635.

27. Banerjee SK, Bonde CG. Total phenolic content and antioxidant activity of extracts of Bridelia retusa Spreng Bark: Impact of dielectric constant and geographical location. J Med Plants Res. 2011;5:817-822.

28. Gull J, Sultana B, Anwar F, Naseer F, Ashraf M, Ashrafuzzaman M. Variation in Antioxidant Attributes at Three Ripening Stages of Guava (Psidium guajava L.) Fruit from Different Geographical Regions of Pakistan. Molecules. 2012;17:3165-3180.

29. Sun YF, Liang ZS, Shan CJ, Viernstein H, Unger F. Comprehensive evaluation of natural antioxidants and antioxidant potentials in Ziziphus jujuba Mill. var. spinosa (Bunge) Hu ex H. F. Chou fruits based on geographical origin by TOPSIS method. Food Chem. 2011;124:1612-1619.

30. Kolawole OT, Ayankunle AA. Seasonal Variation in the Anti-Diabetic and Hypolipidemic Effects of Momordica charantia Fruit Extract in Rats. Eur J Med Plant. 2012;2:177-185. 